\title{
FURTHER EXPERIMENTS ON BIOLOGICAL DIFFERENCES BETWEEN NATURAL SEA WATERS
}

\author{
By Douglas P. Wilson, D.Sc., F.R.P.S. and F. A. J. Armstrong \\ From the Plymouth Laboratory
}

(Text-fig. I)

In a previous paper it was shown that the eggs and larvae of a sea-urchin and of two species of polychaetes 'developed abnormally, or were in poor health, in sea water collected from the English Channel in the region of the Eddystone, although in water collected from the Celtic Sea development was generally normal and healthy' (Wilson, I95I, p. I8). It was suggested that the Channel water lacked some constituent necessary for normal healthy development which was present in water from the Celtic Sea. In a mixture of the two waters the larvae did almost as well as in the Celtic Sea water alone.

It had been planned to continue experimental work on the properties of these two waters when it became evident that further cruises to the westward to obtain Celtic Sea water would not be possible for some time to come. As an alternative to using Celtic Sea water it was thought that water from the Firth of Clyde, which like that from the Celtic Sea is generally characterized by the presence of Sagitta elegans (Russell, 1939; Barnes, 1950), might show similar properties, and be equally suitable for the purpose. Through the kind co-operation of the staff of the Marine Station at Millport, and particularly of Dr H. Barnes, it has been possible to undertake some preliminary experiments using water from the Firth of Clyde. In these experiments the responsibility for the chemical work was undertaken by F.A.J.A. who has prepared an account of the technical details (see pp. 336-8). The form of the experiments, especially the second and third, was agreed upon after discussion in which Dr L. H. N. Cooper and Dr C. P. Spencer sometimes took part.

\section{GeNeral Methods}

Methods followed closely those already described for the earlier experiments with Echinus esculentus L. (Wilson, I95I, p. 5). The concentration of larvae was less than in most of the previous experiments, but more were used than for the thin cultures of Exp. 8B (Wilson, I95I, p. I2). Decanting, to separate swimming blastulae from undeveloped eggs, was unnecessary, as in 1950. 
Pyrex crystallizing dishes of $7 \mathrm{~cm}$. diameter were again used, the quantity of water tested in each being equal at about roo $\mathrm{ml}$.

The Clyde water was collected in carboys cleaned at Plymouth and was sent by passenger train.

\section{Chemical Work \\ Cleaning of Apparatus}

We think that the attention given to this matter has been justified by the uniformity of larval growth in each set of dishes, and that space may properly be given to a detailed description of the methods used.

The 5-gallon glass carboys in which the sea water was collected and kept until filtered were cleaned beforehand by thorough scrubbing inside with a bottle brush, followed by rinsing with I : I sulphuric acid as hot as seemed safe (about $60^{\circ} \mathrm{C}$.). The acid was removed by repeated washing with tap water. Finally, the carboys were washed three times with distilled water, and allowed to drain upside down. The criterion of cleanliness for these carboys and all glassware used in these experiments was that on draining there should be no 'water-break', i.e. that the film of water on the glass spread evenly and did not gather into drops as on a greasy surface. If any article showed a 'water-break' the cleaning was repeated.

Crystallizing dishes, except those cleaned with chromic acid, were immersed completely for about $5 \mathrm{~min}$. in I : I sulphuric acid at about $120^{\circ} \mathrm{C}$., and then rinsed successively with hot tap water and distilled water. They were allowed to drain and dry while inverted on an arrangement of glass plates and rods. During cleaning they were held in a fork of glass rod, and were not touched by hand.

The dishes cleaned with chromic acid cleaning mixture were allowed to stand in the cold mixture for 3 days, after which they were washed in running tap water until the yellow colour disappeared. They were then allowed to stand in clean tap water for 2 days, rinsed with tap water and distilled water and dried in the same way as the other dishes.

Other glassware used was cleaned in hot I : I sulphuric acid and rinsed with tap and distilled water, contact with the hands being always avoided. The larger beakers and vessels used for collecting and treating sea water were cleaned on the inside only.

The Berkefeld filter candles and the rubber and glass tubing used with them had been used for earlier experiments. They were washed as thoroughly as possible with hot tap water and distilled water, sterilized at low pressure in an autoclave, and rewashed with boiling distilled water. The first litre or so of sea water filtered was always discarded.

\section{Measurement of Hydrogen-ion Concentration}

In the first experiment, $\mathrm{pH}$ was measured with a glass electrode and the Cambridge Instrument Company's portable $\mathrm{pH}$ meter. For the later experiments this method was inconvenient, and $\mathrm{pH}$ was estimated by visual colour comparison with Palitzsch buffers, using cresol red and thymol blue as indicators, applying the appropriate salt error corrections given by Buch \& Nynäs (1939). When examining the dishes containing larvae it was found to be quite easy to remove $2 \mathrm{ml}$. with a pipette without much disturbing the water.

\section{Alteration of Hydrogen-ion Concentration of Sea Water}

This was done empirically by adding acid or alkali to portions of the filtered Clyde water, and aerating to bring the water into equilibrium with the carbon dioxide of the atmosphere. 
The reagents used were $0.1 \mathrm{~N}$ solutions of hydrochloric acid and sodium carbonate made from analytical grade chemicals; the quantities used were so small as to make it unlikely that the small changes brought about in salinity or trace elements are significant. Aeration was by means of air filtered through cotton-wool and passed rapidly through the water with a sintered glass gas distribution tube.

On adding acid to lower the $\mathrm{pH}$, equilibrium with the $\mathrm{CO}_{2}$ in the air, i.e. removal of $\mathrm{CO}_{2}$, came about after some ro min. aeration. Trial experiments in raising $\mathrm{pH}$ with sodium hydroxide showed that the reverse process (absorption of $\mathrm{CO}_{2}$ ) was much slower, equilibrium not being obtained after an hour's aeration, and that it was better to use sodium carbonate as the alkali. Even so, equilibration was slow, and had to be assumed to be complete when $30 \mathrm{~min}$. aeration failed to cause any change in $\mathrm{pH}$.

The filtered, but not specially aerated, water was at approximately $\mathrm{pH} 8 \cdot 0$. Solutions of suitable hydrogen ion concentrations were made by using the quantities of acid and alkali listed in Table I.

\section{TABLE I}

\begin{tabular}{|c|c|}
\hline Acid or alkali added & $\mathrm{pH}$ after aeration \\
\hline $6 \mathrm{ml} .0 \cdot 1 \mathrm{~N} \mathrm{HCl} / 1$ & $7 \cdot 82$ \\
\hline I ml. 0. I N HCl$/ 1$. & \\
\hline $2 \mathrm{ml}$. o. I N Na $\mathrm{CO}_{3} / 1$. & $8 \cdot 14$ \\
\hline $4 \mathrm{ml}$. O.I N Na ${ }_{2} \mathrm{CO}_{3} / \mathrm{l}$. & $8 \cdot 18$ \\
\hline $6 \mathrm{ml} .0 . \mathrm{I} \mathrm{N} \mathrm{Na}_{2} \mathrm{CO}_{3} / 1$. & $8 \cdot 28$ \\
\hline $8 \mathrm{ml}$. O. I N Na${ }_{2} \mathrm{CO}_{3} / 1$. & $8 \cdot 45$ \\
\hline
\end{tabular}

\section{Treatment of Sea Water with Carbon}

The procedure was suggested by the successful method used by Braus, Middleton \& Walton (195I) to extract organic substances from drinking and river waters with active carbon. The particular make ('Nuchar C 190' unground) of carbon used by these workers does not seem to be obtainable in this country. On the advice of Messrs Sutcliffe, Speakman and Co. Ltd., we tried their own carbon 207 B, I2-22 mesh, a generous sample of which this firm supplied without charge.

$20 \mathrm{l}$. of the sea water to be treated was driven by air pressure at the rate of $\mathrm{I} 1 \mathrm{l} / \mathrm{hr}$. first through a Berkefeld filter candle and then upward through a glass tube (length $30 \mathrm{~cm}$., int. diam. II mm.) containing $10 \mathrm{~g}$. of the carbon. This almost filled the tube. Fine particles of the carbon were retained by a plug of cotton-wool at the top. The treated water was collected and kept.

\section{Preparation of Extracts}

The carbon through which the sea water had passed was washed by passing $50 \mathrm{ml}$. of distilled water through the tube to remove some of the salt and was then spread on a large clock glass and dried at $60^{\circ} \mathrm{C}$. for $4-5 \mathrm{hr}$. It was then put into a porous alundum thimble previously ignited and extracted with acetone, and was extracted for $6 \mathrm{hr}$. in a Soxhlet apparatus with $100 \mathrm{ml}$. of reagent grade acetone. This solvent was used in the hope that it would extract more water-soluble material than would ether, which was used by Braus et al. (I95I).

A pale greenish yellow acetone solution was obtained. Some partially charred material was seen at the liquid level of the extraction flask where it had obviously been decomposed by the heat of the heating mantle used for the apparatus. After filtration through an acetone-washed No. 43 Whatman paper to remove particles of carbon, the extract was evaporated to dryness at low temperature in a $100 \mathrm{ml}$. beaker and dried in an oven at $60^{\circ} \mathrm{C}$. and weighed. A blank extraction was also performed on a ro g. portion of the carbon. The weights and appearance of the extracts are given in Table II. 
$20 \mathrm{ml}$. of distilled water was added to each beaker, and the mixture warmed to $30-40^{\circ} \mathrm{C}$. to help to break up the residues. That from the E I water dispersed almost at once to give a cloudy pale yellow-green solution, a small amount of greenish brown matter remaining on the bottom. That from the Clyde water did not disperse so readily, and left a larger amount of the greenish brown matter on the bottom of the beaker; the supernatant liquid was a clear yellow green, but paler than from the E I water. The film of residue from the blank extraction did not appear to dissolve in water.

By rubbing the undissolved residues with a glass rod they were dispersed in the liquid as quite small particles, and the extracts were allowed to stand for $3 \mathrm{hr}$., stirred, and each divided into equal portions of $\mathrm{IO} \mathrm{ml}$. On adding these to the E I and Clyde waters, markedly turbid solutions were given by the E I extract, slightly turbid ones by the Clyde extract and clear ones by the blank extract. They were used without further filtration.

Vol. water used (1.)

Wt. of extract (g.) Appearance

\section{Table II. Results of Acetone Extracts}

\begin{tabular}{lll} 
E I water & \multicolumn{1}{c}{$\begin{array}{c}\text { Clyde water } \\
20\end{array}$} & Carbon blank \\
0.0282 & 0.5 & - \\
Waxy greenish yellow & Waxy greenish brown & Thin film of \\
solid with feathery & solid with feathery & whitish deposit \\
brownish cystals to- & brown crystals to- & \\
gether with some & gether with some & \\
whitish opaque & whitish opaque & \\
matter & matter &
\end{tabular}

\section{Addition of Ascorbic Acid to Sea Water}

The contents of a I c.c. ampoule of 'Celin' Vitamin C, Glaxo, stated to contain I00 $\mathrm{mg}$. of ascorbic acid B.P. were diluted to $100 \mathrm{ml}$. with distilled water. Io $\mathrm{ml}$. of this solution were added to I 1 . each of filtered Clyde and E I waters. At the time of preparation these solutions should therefore have had an addition of Io mg./1. of ascorbic acid.

\section{EXPERIMENTAL RESULTS \\ Experiment $I$}

Designed to test three waters, namely water from the international hydrographical station E I, about Io miles W.S.W. of the Eddystone, water from close inshore, and Clyde water. The first would come into the category 'Outside water' as used in the previous paper. In this paper it will be referred to by its international station number.

$E_{\text {I }}$ water collected from the sea surface by means of a wooden bucket. Strained through 200-mesh bolting silk.

Position: $50^{\circ} 02^{\prime} \mathrm{N} ., 4^{\circ} 22^{\prime} \mathrm{W}$.

Date: 17. iii. 52.

Ship: M.F.V. Sula with Dr L. H. N. Cooper.

Salinity: $35 \cdot 25 \% \mathrm{pH}$ (on 2 I. iii. 52 ) $8 \cdot 28$.

Inshore water collected by the same method and on the same day as E I water.

Position: $\frac{1}{2}$ mile W.S.W. Rame Head.

$\mathrm{pH}$ (on 2I. iii. 52) 8.25.

Clyde water collected from sea surface by means of a glass breffit on string handle. Strained through 200-mesh bolting silk. 
Position: approx. mid-channel between Keppel and Fairlie.

Date: I7. iii. 52. Time I5.00 G.M.T. (high-tide I5.26 G.M.T.).

Small boat, with Dr H. Barnes.

Salinity: $32 \cdot 59 \%$ pH (on 21. iii. 52 ) $8 \cdot 17$.

The sea-urchins were trawled on 20 March I952 and kept under circulation overnight. A fertilization from a selected specimen of each sex was made in a mixture of EI and Clyde water at noon the next day. The fertilization was divided equally into three beakers, and each portion washed with six changes of each of the three waters. Five dishes of each water, and five each of equal volumes of Clyde water with $\mathrm{E}_{\mathrm{I}}$ and with Inshore waters were tested.

The results are summarized in Table III. The larvae in the Clyde water did much better than in the E I or Inshore waters, and although the difference was not as spectacular as in some of the earlier experiments it was none the less well marked by the end of the experiment. The difference was, indeed, perceptible as early as the first day and by the third day was unmistakeable. On that day (24. iii. 52) the larvae in the Clyde water had longer arms and were larger and finer looking than those in the EI and Inshore waters. It should be emphasized that up to this time in any one set all five dishes were identical one with another. Afterwards there were slight variations between dishes in a set but they were only of small magnitude. In any dish of Clyde water the larvae were always much better than in any dish containing E I or Inshore water, though one E I dish in particular had from 25 March onwards rather better larvae than the other four.

On 24, 25 and 26 March larvae were removed from some or all of the dishes for closer examination after fixation, and for photographic recording. Careful comparison of the photographs fully confirmed the result already arrived at by examination alive. Three of the photographs are reproduced here (Fig. I). They were obtained by the following method. With a glass dipper each dish of a set of five was thoroughly stirred and one dipper-full withdrawn. The samples from all five dishes were mixed and the larvae then killed by the addition of a small volume of $5 \%$ neutral formalin in sea water. The mixed sample was poured into a boiling tube and allowed to settle. When all the larvae were on the bottom they were withdrawn in a pipette and transferred to a glass dish. A crowded group was chosen at random and photographed. In comparing these photographs it should be borne in mind that the group from the E I water looks better than it should do. Many larvae had already died and decayed leaving little trace, and the photograph is therefore biased in favour of the living and the partially decayed dead. Most of the betterlooking larvae in this EI group came from one particular dish, mentioned above. The other photographs are a fairer assessment of the conditions, for very few larvae had died in the Clyde, or the mixed Clyde and E I waters.

After 26 March, the last day recorded in the table, there was greater variation between dishes, but for another 3 days, until the experiment was 
Table III. Exp. I. Fertilization of Echinus esculentus made on 2I March i952

\begin{tabular}{|c|c|c|c|c|c|}
\hline & Clyde water & E I water & Inshore water & $\begin{array}{l}\text { Mixture of Clyde } \\
\text { and E I waters }\end{array}$ & $\begin{array}{l}\text { Mixture of Clyde } \\
\text { and Inshore waters }\end{array}$ \\
\hline 22. iii. 52 & $\begin{array}{l}\text { Most blastulae swim- } \\
\text { ming strongly at or } \\
\text { near surface }\end{array}$ & $\begin{array}{l}\text { Blastulae dispersed } \\
\text { downwards a little } \\
\text { more than in Clyde } \\
\text { water with more on } \\
\text { the bottom }\end{array}$ & $\begin{array}{l}\text { Blastulae swimming a } \\
\text { little more strongly } \\
\text { than in E I water }\end{array}$ & $\begin{array}{l}\text { Similar to blastulae } \\
\text { in Clyde water }\end{array}$ & $\begin{array}{l}\text { Similar to blastulae } \\
\text { in Clyde water }\end{array}$ \\
\hline 23 . iii. 52 & $\begin{array}{l}\text { Larvae a little more } \\
\text { finely developed } \\
\text { than in E I water }\end{array}$ & $\begin{array}{l}\text { Larvae again dispersed } \\
\text { downwards a little } \\
\text { more than in Clyde } \\
\text { water }\end{array}$ & $\begin{array}{l}\text { Larvae still swimming } \\
\text { a little more strongly } \\
\text { than in E I water }\end{array}$ & $\begin{array}{l}\text { Larvae a little more } \\
\text { finely developed than } \\
\text { in E I water }\end{array}$ & $\begin{array}{l}\text { Larvae a little more } \\
\text { finely developed than } \\
\text { in } \mathrm{E}_{\mathrm{I}} \text { water }\end{array}$ \\
\hline 24. iii. 52 & $\begin{array}{l}\text { Larvae larger and } \\
\text { better formed than } \\
\text { in E I water }\end{array}$ & $\begin{array}{l}\text { Fewer at the surface } \\
\text { and more on the bot- } \\
\text { tom than in Clyde } \\
\text { water }\end{array}$ & $\begin{array}{l}\text { Similar to larvae in } \\
\text { E I water }\end{array}$ & - & - \\
\hline 25. iii. 52 & $\begin{array}{l}\text { Well-formed plutei } \\
\text { swimming well. } \\
\text { Very few dead or } \\
\text { abnormal }\end{array}$ & $\begin{array}{l}\text { Plutei shorter-armed } \\
\text { than in Clyde water, } \\
\text { mainly swimming } \\
\text { well. A moderately } \\
\text { large number dead } \\
\text { or abnormal }\end{array}$ & $\begin{array}{l}\text { Plutei closely } \\
\text { resemble those in } \\
\text { E r water, but there } \\
\text { are fewer dead or } \\
\text { abnormal }\end{array}$ & $\begin{array}{l}\text { Well formed plutei } \\
\text { swimming well, like } \\
\text { those in Clyde water. } \\
\text { Very few dead or } \\
\text { abnormal }\end{array}$ & $\begin{array}{l}\text { Good plutei swim- } \\
\text { ming well, like those } \\
\text { in Clyde water. Very } \\
\text { few dead, a few } \\
\text { abnormal }\end{array}$ \\
\hline 26. iii. 52 & $\begin{array}{l}\text { A fair number of long- } \\
\text { armed plutei swim- } \\
\text { ming in mid-water } \\
\text { and at surface but } \\
\text { majority on bottom, } \\
\text { some of these be- } \\
\text { coming short-armed. } \\
\text { A very few dead }\end{array}$ & $\begin{array}{l}\text { A small number of } \\
\text { medium-armed plutei } \\
\text { swimming, but } \\
\text { majority dead on } \\
\text { bottom, mostly well } \\
\text { decayed. Those still } \\
\text { living mainly short- } \\
\text { armed }\end{array}$ & $\begin{array}{l}\text { Similar to E I water } \\
\text { but not so many dead. } \\
\text { Plutei mostly short- } \\
\text { armed and slightly } \\
\text { inferior to those still } \\
\text { living in E I water }\end{array}$ & $\begin{array}{l}\text { A fair number swim- } \\
\text { ming but majority on } \\
\text { bottom. Larvae in } \\
\text { structure similar to } \\
\text { those in Clyde water. } \\
\text { A very few dead }\end{array}$ & $\begin{array}{l}\text { A fair number swim- } \\
\text { ming but majority on } \\
\text { bottom. In structure } \\
\text { similar to those in } \\
\text { Clyde water. A very } \\
\text { few dead }\end{array}$ \\
\hline
\end{tabular}



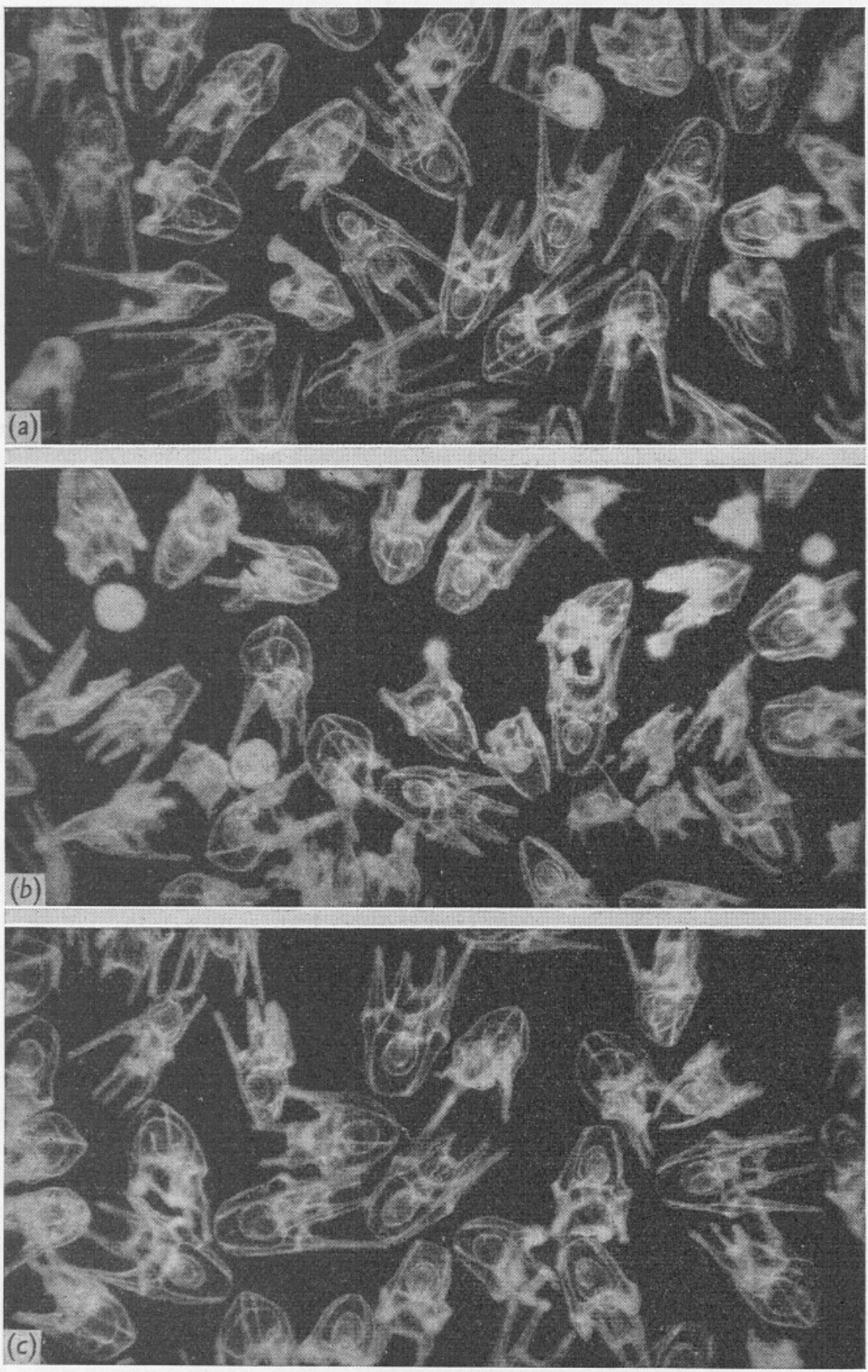

Fig. I. Photomicrographs of larvae from Exp. I. Taken on 26 March 1952, a few minutes after fixation with dilute neutral formalin. $\times 35$. (a) larvae from five dishes of Clyde water; (b) larvae from five dishes of $\mathrm{E}$ I water; (c) larvae from five dishes of Clyde and E I waters mixed in equal proportions. 
ended, the larvae in the Clyde dishes and in the mixtures were better than those still living in the E I water, where almost all were dead.

The larvae which survived in Inshore waters were, on the whole, better in the end than those in $\mathrm{E} I$ water (except for one dish of the latter) but were not as good as in the other waters. Throughout this experiment the room temperature varied between $15 . \mathrm{I}$ and $16 \cdot 6^{\circ} \mathrm{C}$.

\section{Subsidiary Experiment concerning Method of Cleaning Glassware}

Before the experiments began it was suggested to us that the cleaning of the glassware with hot sulphuric acid was unnecessarily dangerous. Arguments were advanced in favour of using potassium bichromate and strong sulphuric acid in the cold-a method commonly adopted for culture glassware. We ourselves agreed that this method of cleaning would be safer and easier to carry out, but we thought that there was a risk that some chromium compound might be left adhering to the glass, even after thorough washing, and that the results might thereby be affected. There was therefore added to Exp. I a set of dishes cleaned in this way to see whether there was, in fact, any difference between the two methods of cleaning.

Six bichromate-cleaned dishes were used, three for Clyde water and three for E I. They were filled in the same manner as those cleaned with pure acid and stood alongside them. Within $24 \mathrm{hr}$. it was seen that the larvae in Clyde water in bichromate-cleaned dishes were swimming less strongly than in Clyde water in pure acid cleaned dishes. On 25 March one of the bichromate dishes contained well-formed plutei similar to those in the five pure acid cleaned dishes, but in the other two the plutei were very malformed and a considerable number were dead. The larvae in E I water in bichromatecleaned dishes differed little in appearance from the abnormal short-armed plutei in the other E I dishes, but by 25 March a higher proportion had died. From these results it may be concluded that it is definitely unwise to use a bichromate cleaning mixture for glassware in which delicate larvae are to be kept.

\section{The Influence of Hydrogen-ion Concentration}

In the earlier work little attention had been paid to the $\mathrm{pH}$ of the sea water used. On one occasion, when there was a marked difference between larvae in waters of different kinds, the $\mathrm{pH}$ had been checked and found to be that of normal sea water in all dishes (Wilson, I95I, Exp. 5, p. 7). Among various suggestions put forward after publication of this earlier work was that the results obtained might have been due to initial $\mathrm{pH}$ difference of the waters concerned. Smith \& Clowes (I924-we are indebted to Mr F. R. H. Jones for this reference) have shown that with Arbacia and Asterias eggs the velocity of cell division is reduced in sea water adjusted to abnormally high or low $\mathrm{pH}$ and that some retardation occurs even at $\mathrm{pH} 7.6$ and 8.5. 'It is doubtful if normal development can be obtained throughout a period of $24 \mathrm{hr}$. 
in solutions more acid than $\mathrm{pH} 7.8$ or more alkaline than $8.4^{\prime}$ (Smith \& Clowes, I924, p. 33I). Although these figures are almost outside the limits likely to be obtained for normal sea water it was obviously desirable that the influence of $\mathrm{pH}$ be considered.

For Exp. I, described above, the initial $\mathrm{pH}$ of the waters after filtration and the $\mathrm{pH}$ of the waters in the dishes after some days was determined with the following results:

Clyde water
EI water
Inshore water
Clyde + E I water
Clyde + Inshore water

\begin{tabular}{|c|c|}
\hline 21. iii. 52 & 25. iii. 52 \\
\hline $\begin{array}{l}8 \cdot 17 \\
8 \cdot 28 \\
8 \cdot 25 \\
8 \cdot 20 \\
-\end{array}$ & $\begin{array}{l}8.08 \\
8.06 \\
8.06 \\
8.07 \\
8.07\end{array}$ \\
\hline
\end{tabular}

It will be observed that there were initial differences between the various waters, but that later on these differences were not so great. Although they were relatively small, they none the less underline the desirability for a more precise investigation.

\section{Experiment II}

This was devoted solely to testing the influence of $\mathrm{pH}$ within the range likely for natural sea water.

Clyde water (collected I7. iii. 52) was adjusted (see pp. 336-7) to six different alkalinities. A fertilization from one male and one female sea-urchin, newly

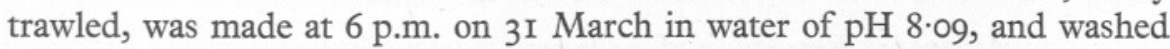
with four changes of the same water. The eggs were distributed in the usual

Table IV. PH of Experimental Dishes

$\begin{array}{rccccc}\text { Set } & \text { 31. iii. 52 } & \text { I. iv. 52 } & \text { 2. iv. 52 } & \text { 3. iv. 52 } & \text { 4. iv. 52 } \\ \text { I } & 7 \cdot 82 & 7 \cdot 80 & 7 \cdot 80 & 7 \cdot 74 & 7 \cdot 76 \\ \text { II } & 7 \cdot 94 & 7 \cdot 92 & 7 \cdot 86 & 7 \cdot 80 & 7 \cdot 84 \\ \text { III } & 8 \cdot 09 & 7 \cdot 99 & 7 \cdot 94 & 7 \cdot 86 & 7 \cdot 87 \\ \text { IV } & 8 \cdot 16 & 8 \cdot 02 & 7 \cdot 98 & 7 \cdot 91 & 7 \cdot 94 \\ \text { V } & 8 \cdot 28 & 8 \cdot 05 & 8 \cdot 04 & 7 \cdot 98 & 7 \cdot 99 \\ \text { VI } & 8 \cdot 38 & 8 \cdot 17 & 8 \cdot 10 & 8 \cdot 05 & 8 \cdot 04\end{array}$

manner, there being five dishes of water of each alkalinity. After distribution $2 \mathrm{ml}$. of water were pipetted from each dish and the $\mathrm{pH}$ of the combined five dishes determined. This was also done on the following days. Table IV gives the results.

It will be observed that in all instances the $\mathrm{pH}$ dropped more or less steadily and that the drop was most pronounced in the higher alkalinities. On the last day some of them showed a slight rise.

Between 4 and 5 p.m. on I April blastulae swam up in all dishes and no differences could be detected. At ro a.m. on 2 April, however, it was noticeable that in set VI more larvae were on the bottom than in any of the others, 
while in set I there were slightly more larvae at the surface than in the others. Sets II-V appeared identical, with most larvae at the surface. The next day, 3 April, no distinctions could be observed, all thirty dishes were alike with about half the larvae at the surface, the others distributed in mid-water and over the bottom. Similarly, on 4 April all dishes seemed equally healthy, with well-formed normal plutei all very much alike. There were hardly any abnormal specimens to be seen. At noon on that day larvae were removed, fixed and photographed from all five dishes of sets I and IV-VI, the method used being that already described (p. 339) for Exp. I. Careful examination of these negatives, as well as of the fixed material with a microscope, revealed no great distinction between any of them. The larvae from sets IV-VI appeared identical, but those from set I had slightly shorter arms and were a little less developed than the others. The difference was very small and could scarcely be observed in living moving plutei.

On 5 April the larvae in all dishes were dying, the flesh of the arms shrinking and the naked rods protruding, and by 6 April most of them were dead.

Throughout this experiment the room temperature varied between 14.9 and $16 \cdot 5^{\circ} \mathrm{C}$.

It is obvious that the $\mathrm{pH}$ differences had had no fundamental effect on early development either as regards speed of the development or the structure of the early pluteus, or on the time of death. In future work slight differences of $\mathrm{pH}$ between sea waters can probably be ignored.

\section{Attempted Extraction of a Growth Factor: Experiment III}

In pursuance of the hypothesis that waters which are favourable to development contain some substance or substances lacking in those which are not, an attempt has been made to extract, with the aid of active carbon, materials from the Clyde water and to add them to E I water. Details of the method used are given above (pp. 337-8); it is only necessary to repeat here that in order to ensure complete control a similar extract was prepared from the E I water and a blank extract from the active carbon alone. Water which had passed through the carbon was also tested. In all, ten tests with a set of five dishes for each test were made. These are listed below, together with the $\mathrm{pH}$, recorded on 24 April from samples of the original waters stored in glass containers:

\begin{tabular}{rlc}
\multicolumn{1}{c}{ Set } & & $\mathrm{pH}$ \\
I & EI water & $7 \cdot 96$ \\
II & E I water+E I extract & $7 \cdot 94$ \\
III & E I water + Clyde extract & $7 \cdot 94$ \\
IV & E I water + blank extract & 7.99 \\
V & Clyde water & $7 \cdot 94$ \\
VI & Clyde water + E I extract & $7 \cdot 92$ \\
VII & Clyde water + Clyde extract & $7 \cdot 92$ \\
VIII & Clyde water + blank extract & $7 \cdot 87$ \\
IX & E I water through carbon & 7.99 \\
X & Clyde water through carbon & 7.99
\end{tabular}


The waters used were newly collected as follows:

E I water collected from sea surface with wooden bucket. Not strained.

Position: $50^{\circ} 02^{\prime}$ N., $4^{\circ} 22^{\prime} \mathrm{W}$.

Date: I6. iv. 52.

Ship: R.V. Sabella with F. A. J. A.

Salinity: $35 \cdot 26 \%$.

Clyde water collected from sea surface by dipping with a glass breffit. Strained through 200-mesh bolting silk.

Date: I6. iv. 52. Time, I I.00 G.M.T. (high tide I6.07 G.M.T.).

Position: mid-channel between Keppel Pier and Fairlie.

Small boat with Dr H. Barnes.

Salinity: $32 \cdot 75 \%$.

The sea-urchins were trawled on 22 April and a fertilization from one male and one female was made at 5 p.m. the same day. A mixture of equal parts of Clyde and E I waters was used, the fertilized eggs being divided equally and each half washed in six changes of one or the other water. The eggs which were transferred to the waters which had been passed through active carbon were further washed in the carbon-treated water before being put into the dishes. The glass dipper method of transference (Wilson, I95I, p. 5) ensured that very nearly the same numbers of eggs were put into each of the fifty test dishes.

At the first examination on the following day (23 April) it was at once evident that in all dishes to which Clyde or EI extracts had been added (sets II, III, VI and VII) the eggs had cleaved irregularly and had died in early cleavage. The extracts had proved poisonous.

In all the other sets the embryos were alive. At $9.30 \mathrm{a} . \mathrm{m}$. the blastulae were still within the fertilization membrane and motionless. It was observed that almost I00 \% of the eggs had fertilized but that about Io \% had developed somewhat abnormally and it appeared that the fertilization was not quite as good as those for Exps. I and II. Shortly after noon the blastulae, free from the membrane, were beginning to swim up, noticeably more so in some sets than in others (see Table V). At this early stage the blastulae in the E I water, especially in that which had been passed through carbon, lagged behind all the others, although those in the E I water to which the blank extract had been added were reasonably active. The blastulae in the Clyde water with blank extract led all the rest. After this early stage there was from time to time some variation, first one set taking the lead and then another. It was very noticeable how all five dishes in any one set presented a uniform appearance. By the fourth or fifth day there was relatively little to choose between sets I, IV, V and VIII, although IV and VIII (the waters to which blank extracts had been added) seemed to be slightly inferior to the other two. The distinction was too subtle to indicate in the table. On 24 April the $\mathrm{pH}$ of one dish in each set was determined and is recorded in the table. On 26 April the larvae were mostly good four-armed plutei, but they were not quite so well developed in any of the dishes as those in the Clyde water of Exp. I of 
Table V. Exp. III. Fertilization of EChinUs ESCUlentus MAde ON 22 April I952

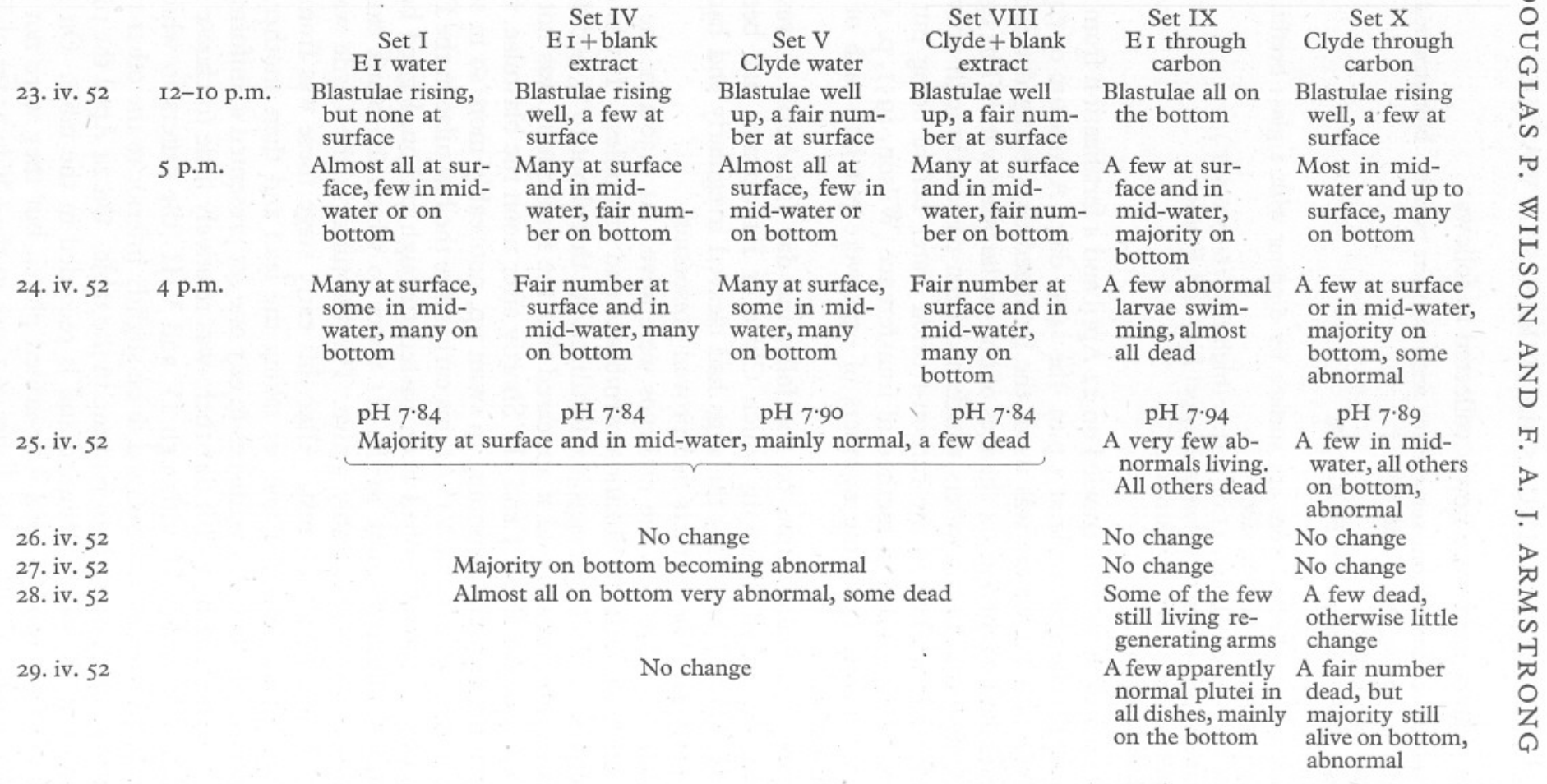


the same age and of which photographs were available for comparison. There was more variation in form and there was a greater proportion of plutei abnormal in varying degree. By the next day all were becoming abnormal, flesh was shrinking down the arms and exposing the rods, which eventually broke off. Not many larvae had died after another 2 or 3 days.

The main interest of this experiment derives from the condition of the larvae in the waters which had been passed through the active carbon, which was known (see pp. 337-8) to have extracted substances from them. In the carbon-treated E I water larvae showed little vigour and soon most of them were dead. In carbon-treated Clyde water, on the other hand, the larvae showed more vigour in keeping up off the bottom, although after a few days most of them were lying on it. They failed to develop long arms but most remained alive, stunted in their growth. Towards the end of the experiment some of the few larvae still surviving in set IX, a few in each dish (one dish had more than the others), unexpectedly grew arms which they had not had previously and to all appearance were normal plutei. Others had partially grown arms. This occurred, it should be noted, at a time when in all the other dishes the larvae had lost the arms which they had previously possessed. These newly formed plutei, however, were very lethargic, lying on the bottoms of the dishes and rarely swimming. The water in the dishes was slightly milky, probably from bacterial growth.

The temperature of the room throughout the experiment was very uniform, varying between $15^{\circ} 0$ and $15.7^{\circ} \mathrm{C}$.

\section{Subsidiary Experiment with Ascorbic Acid}

Collier, Ray \& Magnitzky (I950) of U.S. Fish and Wildlife Service found a correlation between the pumping rate of Ostrea virginica and a factor naturally present in minute amounts in sea water which they designated as 'carbohydrate' or some other compound quantitatively associated with the carbohydrates responding to the test.

In a letter to Dr L. H. N. Cooper, dated I2 March I952, Dr John Lyman stated that U.S. Fish and Wildlife Service investigators now believe that this substance is ascorbic acid (vitamin C) and Dr Lyman suggested that the growth factor lacking in the Channel water might possibly be ascorbic acid. In order to test this suggestion there were included in Exp. III a set of five dishes of E I water to which Io mg./1. of ascorbic acid had been added (see p. $33^{8}$ for details) and another set of five containing Clyde water with ascorbic acid. Except that the blastulae in the E I dish with ascorbic acid swam up off the bottom a little earlier than in the untreated EI water the behaviour and development of the larvae in these waters dosed with ascorbic acid was closely similar, throughout the experiment, to the larvae in the untreated waters.

This experiment cannot be considered conclusive. It was tried out in E I water which proved better than usual and with a batch of eggs which may have been of inferior quality (see p. 345). 


\section{Discussion}

It has now been shown that sea waters from two distinct localities, namely the Celtic Sea and the Firth of Clyde, are sometimes more suitable for laboratory rearings of Echinus esculentus than is sea water from the English Channel in the neighbourhood of Plymouth. Both of the better waters come from sea areas known to be normally characterized by a Sagitta elegans plankton, whereas the poorer Channel water supports only a less abundant $S$. setosa community. No doubt the relative merits of the two sorts of water vary from time to time. This seems to be indicated by those earlier experiments in which the larvae failed to develop properly in both types of water, and by Exp. III of the present series. In this latter experiment the larvae in the E I water were practically indistinguishable from those in the water from the Clyde, although in neither was the rearing one of the best. The plutei showed a greater variation of structure than usual, about half being to greater or lesser degree subnormal. This may have been due to variability in the condition of the eggs, but on this aspect the experiment was not controlled. Nevertheless, the larvae in the E I water did better than previously, implying that at times the water occupying this Channel station will be fairly favourable for developing Echinus esculentus. That the larvae of this species do develop somewhere in the region is obvious from the numbers of adults present on the trawling grounds (but see Wilson, I95I, p. I8). Late larvae of the species were seen in plankton catches taken off Plymouth in May and June 195I, but in that year no laboratory tests of the sea water were made.

The results of mixing waters (Exp. I) are most instructive. They are probably most easily explained by assuming that the poor condition of the larvae in the EI and Inshore waters was due to deficiency of something which was present in the Clyde water. In previous experiments Celtic water had appeared to supply some necessary ingredients to similar mixtures. This conjecture that the better waters contain some essential material which is deficient in the poorer waters seems to be supported by the results of Exp. III where the larvae did so badly in both good and bad waters after they had been passed through activated carbon. Although there is no definite proof, it would seem more probable that the carbon removed needed subtances from the water than that it added something deleterious. Indeed it is known that the carbon extracted a considerable quantity of matter which was recovered with acetone (see p. 337). The acetone extracts from the carbon alone, on the other hand, had little or no effect on the larvae in the waters to which they were added.

The much delayed outgrowth of arms on some of the few surviving larvae in the carbon-treated E I water (set IX of Exp. III) is of particular interest. It raises the question whether the early death and decay of the majority of the larvae in these dishes had restored to the water, perhaps by bacterial action, the material needed. Alternatively, perhaps, the larvae had obtained it in particulate form by way of the mouth. 


\section{SUMMARY}

In one experiment sea water from the Firth of Clyde yielded better cultures of Echinus esculentus larvae than did sea waters from two positions in the English Channel.

From the Clyde water materials of unknown composition were extracted, using active carbon and acetone. The addition of these materials to both Clyde and Channel waters resulted in the death of the Echinus eggs during early cleavage. A similar extraction from Channel water had the same effect. The Clyde and Channel waters from which these materials had been extracted gave poor abnormal cultures, especially the Channel water in which most larvae died early. A few, however, survived, and later on some of these grew into almost normal plutei.

It is shown that alkalinities between $\mathrm{pH} 7.82$ and 8.38 have little or no effect on the growth and form of early Echinus larvae.

The addition of ascorbic acid to both Clyde and Channel waters produced little or no improvement, but the experiment was in the main inconclusive.

Some evidence is advanced that English Channel water is not always an unfavourable medium for the development of sea-urchin larvae.

Some glass dishes which had been cleaned with a cleaning mixture consisting of potassium bichromate and sulphuric acid gave rise to abnormal and unhealthy larvae, while similar dishes cleaned with hot sulphuric acid did not.

Details of the chemical methods used in these investigations are given.

\section{REFERENCES}

Barnes, H., I950. Sagitta setosa J. Müller in the Clyde. Nature, Vol. I66, p. 447.

Braus, H., Middleton, F. M. \& Walton, G., I95I. Organic chemical compounds in raw and filtered surface waters. Anal. Chem., Vol. 23, pp. II60-4.

Buch, K. \& NYNÄs, O., I939. Studien über neuere $p$ H-Methodik mit besonderer Berücksichtigung des Meerwassers. Acta Acad. Abo. Math. et Phys., Vol. I2, 4I pp.

CollieR, A., RAY, S. \& MAGNitzky, W., I950. A preliminary note on naturally occurring organic substances in sea water affecting the feeding of oysters. Science, Vol. III, pp. I5I-2.

Russell, F. S., I939. Hydrographical and biological conditions in the North Sea as indicated by plankton organisms. Fourn. Cons. Int. Explor. Mer, Vol. I4, pp. I7I-92.

SMITH, H. W. \& Clowes, G. H. A., 1924. The influence of hydrogen ion concentration on the development of normally fertilized Arbacia and Asterias eggs. Biol. Bull. Woods Hole, Vol. 47, pp. 323-32.

WILson, D. P., I95I. A biological difference between natural sea waters. Fourn. Mar. Biol. Assoc., Vol. 30, pp. I-26. 